\title{
Multiplex ligation dependent probe amplification analysis of KAL1, GNRH1, GNRHR, PROK2 and PROKR2 in male patients with idiopathic hypogonadotropic hypogonadism
}

\author{
Przeprowadzona z wykorzystaniem zależnej od ligacji multipleksowej \\ amplifikacji sond analiza genów KAL1, GNRH1, GNRHR, PROK2 \\ i PROKR2 u pacjentów płci męskiej z idiopatycznym hipogonadyzmem \\ hipogonadotropowym \\ Yalcin Basaran ${ }^{1}$, Erol Bolu' ${ }^{1}$, Hilmi Umut Unal', Rahsan Ilikci Sagkan ${ }^{3}$, Abdullah Taslipinar', \\ Taner Ozgurtas ${ }^{4}$, Ugur Musabak
}

${ }^{1}$ Departments of Endocrinology and Metabolism, Gulhane School of Medicine, Ankara, Turkey

${ }^{2}$ Departments of Nephrology, Gulhane School of Medicine, Ankara, Turkey

${ }^{3}$ Departments of Immunology, Gulhane School of Medicine, Ankara, Turkey

${ }^{4}$ Departments of Biochemistry, Gulhane School of Medicine, Ankara, Turkey

\begin{abstract}
Introduction: The purpose of this study was to determine the prevalence of KAL1, GNRH1, GNRHR, PROK2, and PROKR2 copy number variations in patients with idiopathic hypogonadotropic hypogonadism (IHH).

Material and methods: 86 hypogonadal males (76 diagnosed with normosmic idiopathic hypogonadotropic hypogonadism [nIHH] and ten with Kallmann syndrome [KS]) and 95 healthy control individuals were studied for the presence of aforementioned genomic rearrangements, using multiplex ligation dependent probe amplification (MLPA).

Results: We detected that of the 86 patients, three with KS had a deletion of the KAL1 gene in exon 9, one of whom also carried a duplication in exon 11; and three with NIHH had a duplication of the PROK2 gene in exon 3; a deletion of the GNRHR gene in exon 1; and a duplication of the same gene in exon 2, respectively. No abnormalities were found in the patient group for the PROKR2 and GNRH1 genes. In addition, no genomic rearrangements were identified in the healthy control individuals for the described genes.

Conclusions: Defining the genetic basis of disease is essential to improve our understanding of this complex disorder, and could be useful for genetic counselling and for directing therapy. In addition, discovering the association between genetic mutations and disease is important for our better understanding of normal reproductive functions. (Endokrynol Pol 2013; 64 (4): 285-292)
\end{abstract}

Key words: hypogonadism, KAL1, GNRH1, GNRHR, PROK2, PROKR2, MLPA

\section{Streszczenie}

Wstęp: Celem badania było ustalenie rozpowszechnienia zmienności liczby kopii genów KAL1, GNRH1, GNRHR, PROK2 i PROKR2 u pacjentów z idiopatycznym hipogonadyzmem hipogonadotropowym ( $\mathrm{IHH}$, idiopathic hypogonadotropic hypogonadism).

Materiał i metody: Obecność wymienionych wyżej rearanżacji genomowych zbadano metodą zależnej od ligacji multipleksowej amplifikacji sond (MLPA, multiplex ligation dependent probe amplification) u 86 mężczyzn z hipogonadyzmem - w tym u $76 \mathrm{z}$ rozpoznaniem IHH przebiegającego bez zaburzeń węchu (nIHH, normosmic idiopathic hypogonadotropic hypogonadism) i u $10 \mathrm{z}$ rozpoznaniem zespołu Kallmanna (KS, Kallmann syndrome) — oraz u 95 zdrowych osobników kontrolnych.

Wyniki: U 3 pacjentów z KS stwierdzono delecję w obrębie genu KAL1 w egzonie 9, przy czym u jednego z nich występowała też duplikacja w egzonie 11. Z kolei łącznie u 3 pacjentów z nIHH stwierdzono: duplikację w obrębie genu PROK2 w egzonie $3 \mathrm{u}$ jednego pacjenta, delecję w obrębie genu GNRHR w egzonie 1 u drugiego pacjenta oraz duplikację obrębie tego samego genu w egzonie 2. Jeśli zaś chodzi o geny PROKR2 i GNRH1, to w grupie pacjentów nie stwierdzono żadnych nieprawidłowości w tym zakresie. Nie stwierdzono też żadnych rearanżacji genomowych w zakresie wymienionych genów u zdrowych osobników kontrolnych.

Wnioski: Określanie podłoża genetycznego ma ogromne znaczenie dla pogłębiania wiedzy na temat tej złożonej choroby i może być przydatne w poradnictwie genetycznym i ustalaniu leczenia. Ponadto odkrywanie powiązań pomiędzy mutacjami genetycznymi a omawianą chorobą ma duże znaczenie dla pogłębiania wiedzy na temat prawidłowego funkcjonowania układu rozrodczego. (Endokrynol Pol 2013; 64 (4): 285-292)

Stowa kluczowe: hipogonadyzm, KAL1, GNRH1, GNRHR, PROK2, PROKR2, MLPA

Yalcin Basaran M.D., Department of Endocrinology and Metabolism, Gulhane School of Medicine, 06018, Etlik, Ankara, Turkey, tel.: +90 31230442 16, fax: +90 31230442 00, e-mail: yalcinbasaran@yahoo.com 


\section{Introduction}

Hypogonadism is defined as the failure in production of gonadal hormones, which may be due to lack of gonadotropin secretion (hypogonadotropic hypogonadism) or due to primary testicular failure (hypergonadotropic hypogonadism). The distinction between these disorders is made by the measurement of the serum concentrations of gonadotropins. IHH may be associated with anosmia or hyposmia (KS), or with a normal sense of smell (nIHH).

To date, several mutations have been identified as the underlying cause of the disease. However, they account for the molecular basis of less than $30 \%$ of all patients with $\mathrm{IHH}$, which suggests that additional genes need to be discovered. These mutations can be divided into four groups: 1) those affecting $\mathrm{GnRH}$ neuronal migration and functions; 2) those affecting $\mathrm{GnRH}$ synthesis and secretion; 3) those affecting hypophyseal response to GnRH; and 4) those affecting gonadotropin biosynthesis. Each of these steps is characterised by different phenotypic expressions.

The aim of the present study was to detect the prevalence of sequence variations of the KAL1, GNRH1, GNRHR, PROK2 and PROKR2 genes and to identify their role in the pathogenesis of the disease. Because it has several advantages over traditional screening methods, multiplex ligation dependent probe amplification (MLPA) was used to identify genomic rearrangements.

\section{Material and methods}

\section{Patients and controls}

86 hypogonadotropic hypogonadal men (76 with $\mathrm{nIHH}$ and ten with KS), ages ranging from 19 to 25 years (21.70 \pm 1.80 years [mean $\pm \mathrm{SD}$ ]) and 95 age-matched healthy eugonadal males of the same ethnic origin (21.68 \pm 2.13 years [mean $\pm \mathrm{SD}$ ]) were included in the study between May 2006 and October 2009 at the Department of Endocrinology and Metabolism, Gulhane School of Medicine, Ankara, Turkey.

Subjects with no history of recent or previously taken medication, aged over 18 (and bone age of $<18$ years), with symptoms and signs of hypogonadism (such as lack of libido, inability to have or maintain erec- tion, Tanner stages 1 to 2 ), with subnormal testosterone levels and normal or reduced serum LH and FSH concentrations and those with normal karyotype (46, XY) served as the patient group. Subjects with constitutional delay of puberty or other hormonal imbalances were excluded from the study. All participants were tested with strong stimuli such as coffee, onion and garlic, and the patient group underwent MRI of the olfactory bulbs and tracts. Individuals with decreased sense of smell or anosmia were considered as having KS and those with normal sense of smell and with no evidence of morphological changes on the radiological examination were considered to have $\mathrm{nIHH}$.

All patients and the control subjects were informed about the aim and procedure of the study and written informed consent from all participants was obtained at the beginning. The study was approved by the ethics committee of the Gulhane School of Medicine.

\section{Biochemical analysis}

Blood samples withdrawn from a single vein at around 8 am after an overnight fast were collected into non-anticoagulated tubes (Grainer, Australia) and centrifuged at 5,000 rpm for 10 minutes at room temperature. All serums were stored in the deep freeze at $-80^{\circ} \mathrm{C}$ prior to use. Total T, FSH and LH levels were determined by a chemiluminescence immunoassay method using an automated immunoassay analyser (E170, Roche, Hitachi Corporation, Osaka, Japan) (Table I).

\section{Genetic analysis}

DNA was extracted from white blood cells of all patients and controls using BioRobot GenoVision Geno M-6 and EZ1 DNA Blood kit (Qiagen, Germany), according to the manufacturer's instructions. A total of $125 \mathrm{ng}$ DNA in $5 \mu \mathrm{L}$ for each MLPA reaction was used.

\section{DNA denaturation}

$5 \mu \mathrm{L}$ of DNA in $0.2 \mathrm{ml}$ PCR-tubes were dissolved in TE (10 mM Tris-HCl pH $8.2+0.1 \mathrm{mM}$ EDTA). The tubes were placed in a thermocycler and DNA samples were denatured for 5 minutes at $98^{\circ} \mathrm{C}$ and immediately cooled to $25^{\circ} \mathrm{C}$ before opening the thermocycler.

Table I. Hormonal profiles of the patients and control subjects

Tabela I. Profile hormonalne pacjentów i osobników kontrolnych

\begin{tabular}{lccc}
\hline Parameters & Study Group $(\mathbf{n}=\mathbf{8 6})$ & Control Group (n = 95) & p \\
\hline Age (years) & $21.70 \pm 1.80$ & $21.68 \pm 2.13$ & 0.75 \\
\hline Total testosterone $[\mathrm{ng} / \mathrm{dL}]$ & $65.11 \pm 51.25$ & $546.92 \pm 131.12$ & $<0.001$ \\
\hline FSH $[\mathrm{mlU} / \mathrm{mL}]$ & $0.80 \pm 0.59$ & $5.27 \pm 2.07$ & $<0.001$ \\
\hline LH $[\mathrm{mlU} / \mathrm{mL}]$ & $0.47 \pm 0.55$ & $5.31 \pm 1.97$ & $<0.001$ \\
\hline
\end{tabular}

Data expressed as mean \pm SD 


\section{Hybridisation reaction}

$3 \mu \mathrm{L}$ of a hybridisation master mix (1.5 $\mu \mathrm{L}$ MLPA buffer $+1.5 \mu \mathrm{L}$ probemix) was added to each sample tube and mixed well. The thermocycler programme was continued for 1 minute at $95^{\circ} \mathrm{C}$, and then for 16 hours at $60^{\circ} \mathrm{C}$.

\section{Ligation reaction}

A ligase master mix ( $3 \mu \mathrm{L}$ Ligase-65 buffer $\mathrm{A}+3 \mu \mathrm{L}$ Ligase- 65 buffer $\mathrm{B}+25 \mu \mathrm{L} \mathrm{dH}_{2} \mathrm{O}$ ) was prepared and mixed well by pipetting gently up and down. Then $1 \mu \mathrm{L}$ of Ligase- 65 was added and mixed again. Thermocycler was paused at $54^{\circ} \mathrm{C}$ and the $32 \mu \mathrm{L}$ of the ligase master mix was added to each reaction tube. The programme was continued for 15 minutes at $54^{\circ} \mathrm{C}$, followed by 5 minutes at $98^{\circ} \mathrm{C}$ for heat inactivation of the Ligase- 65 enzyme and then paused at $15^{\circ} \mathrm{C}$.

\section{PCR reaction}

A PCR buffer mix (4 $\mu \mathrm{L}$ SALSA PCR buffer $+26 \mu \mathrm{L}$ $\mathrm{dH}_{2} \mathrm{O}$ ) was prepared and mixed briefly by vortexing. Then the $30 \mu \mathrm{L}$ of PCR buffer mix was added to new tubes for the PCR reaction. $10 \mu \mathrm{L}$ of each ligation product was transferred to its corresponding PCR tube at room temperature. A polymerase master mix $(2 \mu \mathrm{L}$ SALSA PCR-primers $+2 \mu$ L SALSA Enzyme dilution buffer $+5.5 \mu \mathrm{L} \mathrm{dH}_{2} \mathrm{O}+0.5 \mu \mathrm{L}$ SALSA Polymerase) was prepared and stored on ice until use. The thermocycler was heated to $60^{\circ} \mathrm{C}$. The PCR tubes were placed in it and $10 \mu \mathrm{L}$ polymerase mix was added to each tube. After mixing by pipetting gently up and down the thermocycler programme was continued immediately. 35 PCR cycles were run $\left(30\right.$ seconds $95^{\circ} \mathrm{C} ; 30$ seconds $60^{\circ} \mathrm{C}$; 60 seconds $72^{\circ} \mathrm{C}$ ) and ended with 20 minutes incubation at $72^{\circ} \mathrm{C}$ and then paused at $15^{\circ} \mathrm{C}$.

\section{Fragment separation}

Following the PCR reaction, a mix $(0.75 \mu \mathrm{L}$ of the PCR reaction $+0.75 \mu \mathrm{L}$ water $+0.5 \mu \mathrm{L}$ size standard +13.5 $\mu \mathrm{L}$ HiDi formamide) was incubated for 2 minutes at $94^{\circ} \mathrm{C}$ and stored on ice. PCR products were separated by capillary electrophoresis using a Beckman Coulter CEQ-8000 Genetic Analyser.

\section{MLPA data analysis}

Exonic deletions and duplications were examined by MLPA using commercial kits. The P132-Kallmann1 kit (MRC Holland, Amsterdam, Netherlands) contains MLPA probes for each of the 14 KAL1 exons, and the P133 Kallmann-2 kit contains (MRC Holland, Amsterdam, Netherlands) MLPA probes for most exons of the FGFR1 gene (11 of the 18 exons), for some of the NELF (three of the 16 exons), GPR54 (three of the five exons), GNRH1 (three of the four exons), and for each of the GNRHR, PROK2 and PROKR2 genes.
Data was evaluated using Genotyper 2.0 (Applied Biosystems, Foster City, CA, USA). For analysis of the data, Coffalyser software (an Excel-based program) was used. Peak areas for each exon were converted into an Excel file and the relative DNA copy number ratios of each fragment were compared to the same fragments from two or three healthy subjects.

\section{Statistical analysis}

Statistical evaluation was performed using the Statistical Package for the Social Sciences 15.0 (SPSS, Inc., Chicago, IL, USA). Parametric data was expressed as mean \pm SD. The normality of distribution of continuous variables was evaluated using the Kolmogorov-Smirnov test. For between-group comparisons, if continuous variables were acceptable with normal distribution, we used Student's t test; if not, we used the Mann-Whitney $\mathrm{U}$ test. A p-value of $<0.05$ was considered statistically significant.

\section{Results}

Three patients with KS had deletions in exon 9 of the KAL1 gene (probe target sequence: 5941-L05940) and one of these patients had also a duplication in exon 11 of the same gene (probe target sequence: 4427-L03813) (Figs. 1-3). Three patients with nIHH had a duplication in exon 3 of the PROK2 gene (probe target sequence: 11953-L12773) (Fig. 4), a deletion in exon 2 of the GNRHR gene (probe target sequence: 4447-L05586) (Fig. 5), and a duplication in exon 1 of the GNRHR gene (probe target sequence: 4445-L03831) (Fig. 6), respectively. No deletions/duplications were identified in the GNRH1 and PROKR2 genes in the patient group and none of the mentioned genomic rearrangements was detected in the control subjects.

In summary, using MLPA for the described genes, seven genomic rearrangements were present in 6/86 (6.9\%) patients with IHH. If only patients with $\mathrm{nIHH}$ were considered, 3/76 (3.9\%) had previously described deletions or duplications; and if only KS patients were considered, 3/10 (30\%) had KAL1 genomic rearrangements, one of whom carried both deletion and duplication in the same gene (Table II).

When the genes were considered separately, genomic rearrangements in the KAL1, PROK2 and GNRHR were found in 3/86 (3.4\%) (in 0/76 (0\%) with nIHH and in $3 / 10(30 \%$ ) with KS), in $1 / 86(1.1 \%$ ) (in $1 / 76$ $(1.3 \%)$ with nIHH and in $0 / 10(0 \%)$ with KS), and in 2/86 $(2.3 \%)$ (in 2/76 (2.6\%) with nIHH and in 0/10 (0\%) with KS) hypogonadal patients, respectively.

All patients with KS were found to have some degree of high-arched palate and dental malocclusion, compared to only a small minority of nIHH patients. These 


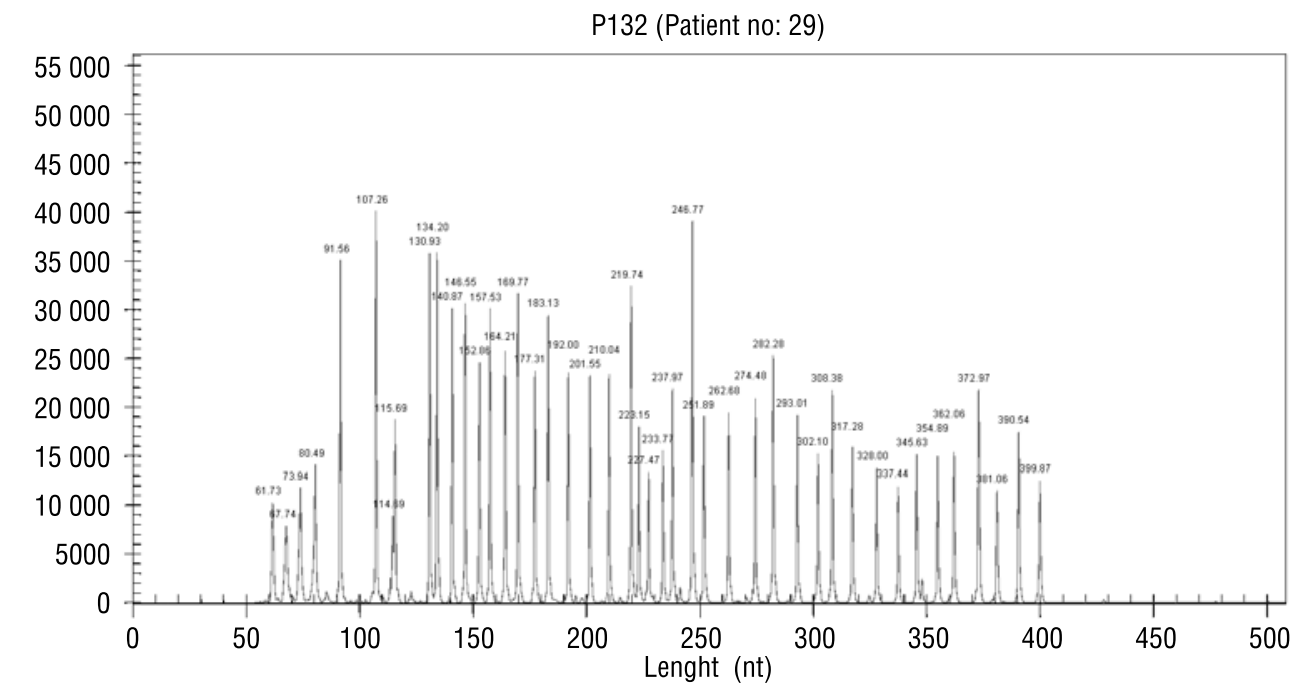

Figure 1. Deletion in exon 9 of the KAL1 gene (probe target sequence: 5941-L05940)

Rycina 1. Delecja w egzonie 9 genu KAL1 (sekwencja docelowa sondy: 5941-L05940)

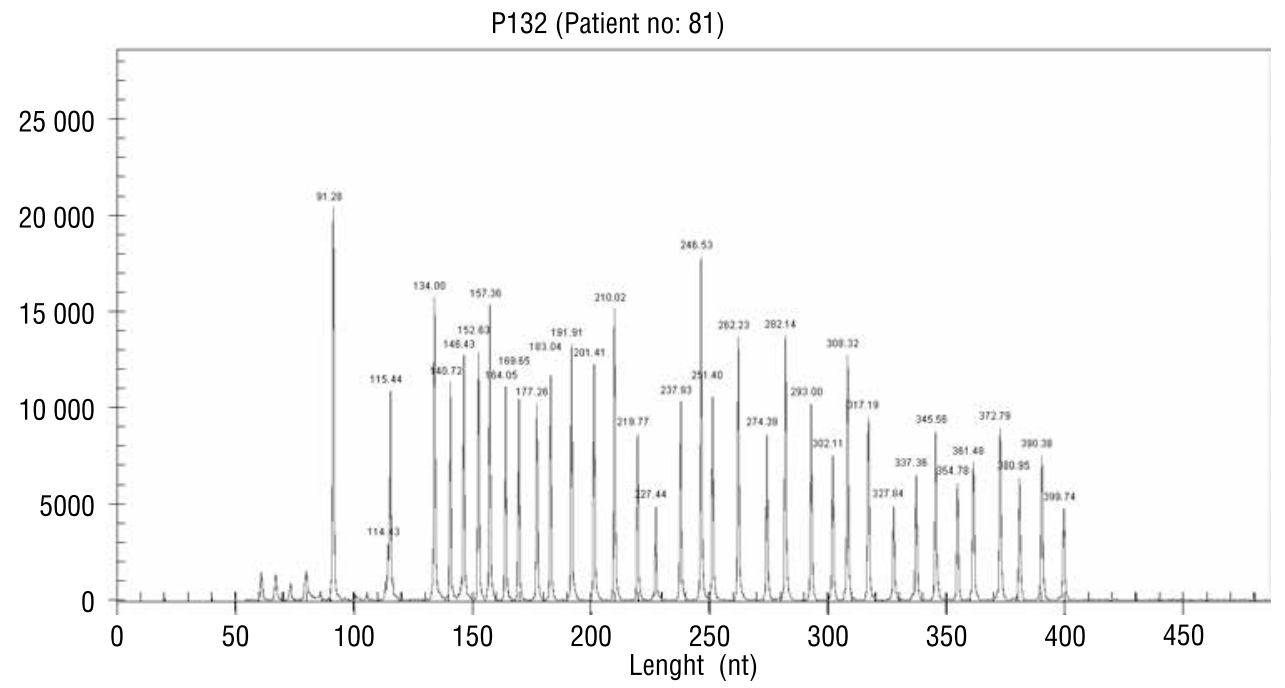

Figure 2. Deletion in exon 9 of the KAL1 gene (probe target sequence: 5941-L05940) and duplication in exon 11 of the same gene (probe target sequence: 4427-L03813)

Rycina 2. Delecja w egzonie 9 genu KAL1 (sekwencja docelowa sondy: 5941-L05940) i duplikacja w egzonie 11 tego samego genu (sekwencja docelowa sondy: 4427-L03813)

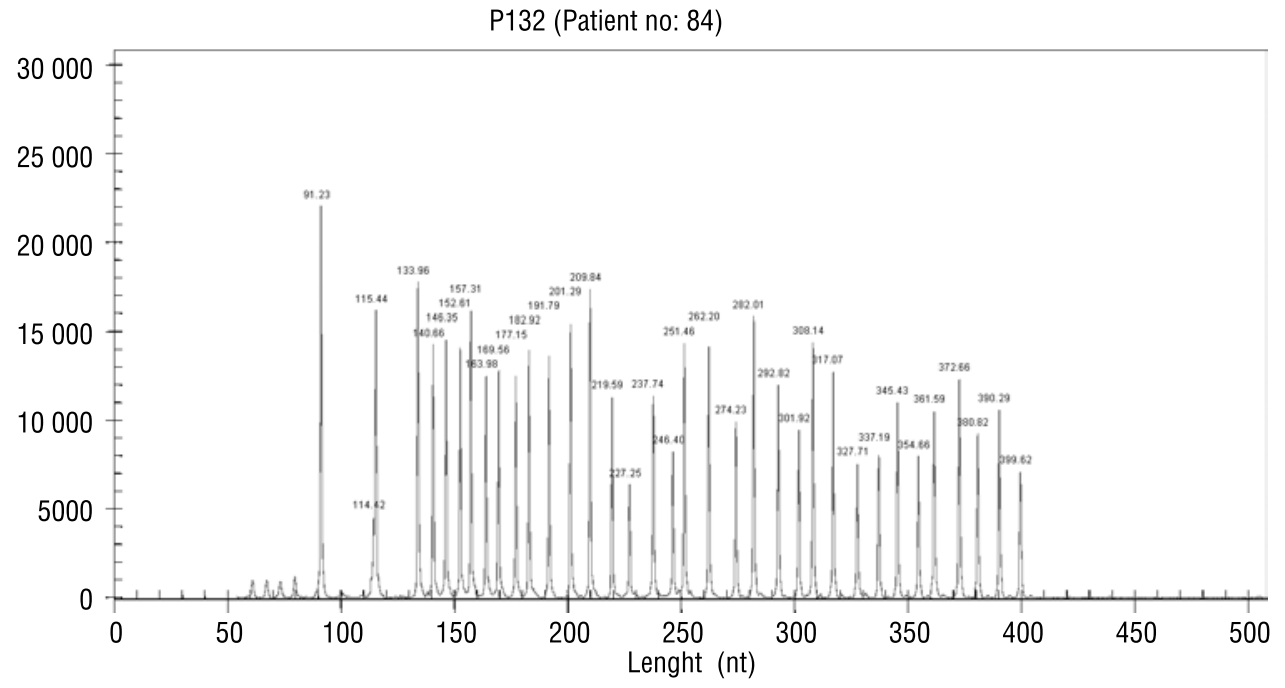

Figure 3. Deletion in exon 9 of the KAL1 gene (probe target sequence: 5941-L05940)

Rycina 3. Delecja w egzonie 9 genu KAL1 (sekwencja docelowa sondy: 5941-L05940) 


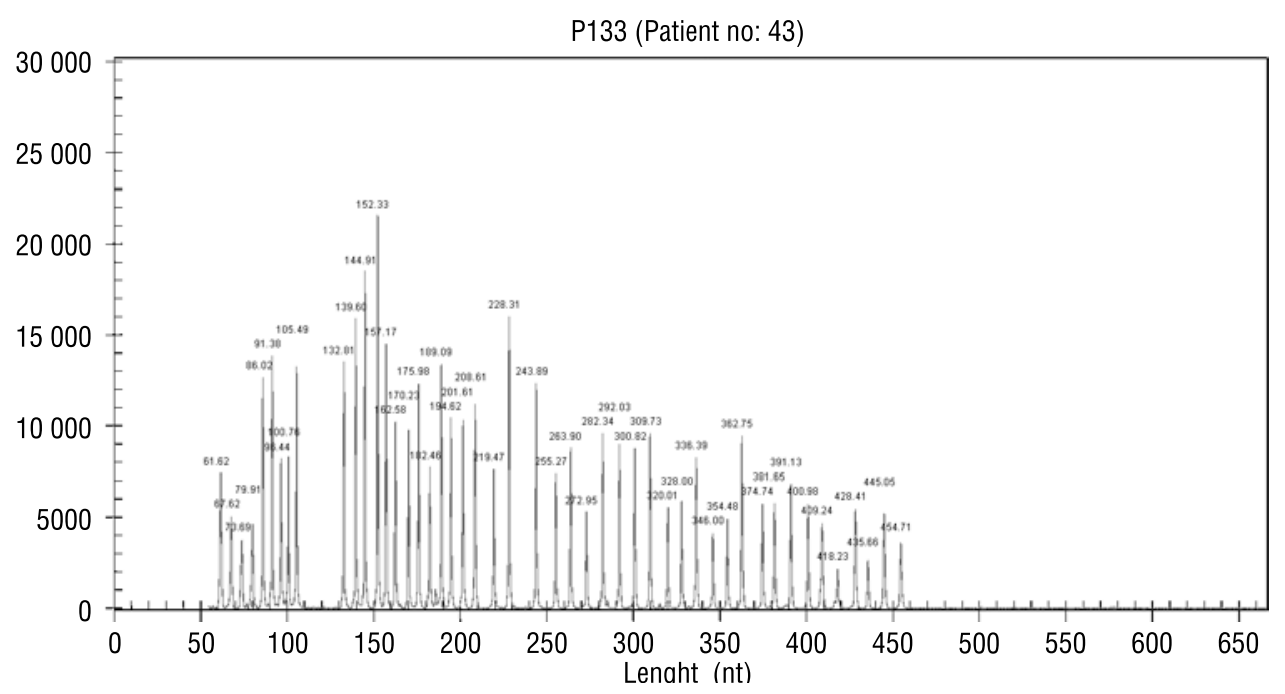

Figure 4. Duplication in exon 3 of the PROK2 gene (probe target sequence: 11953-L12773)

Rycina 4. Duplikacja w egzonie 3 genu PROK2 (sekwencja docelowa sondy: 11953-L12773)

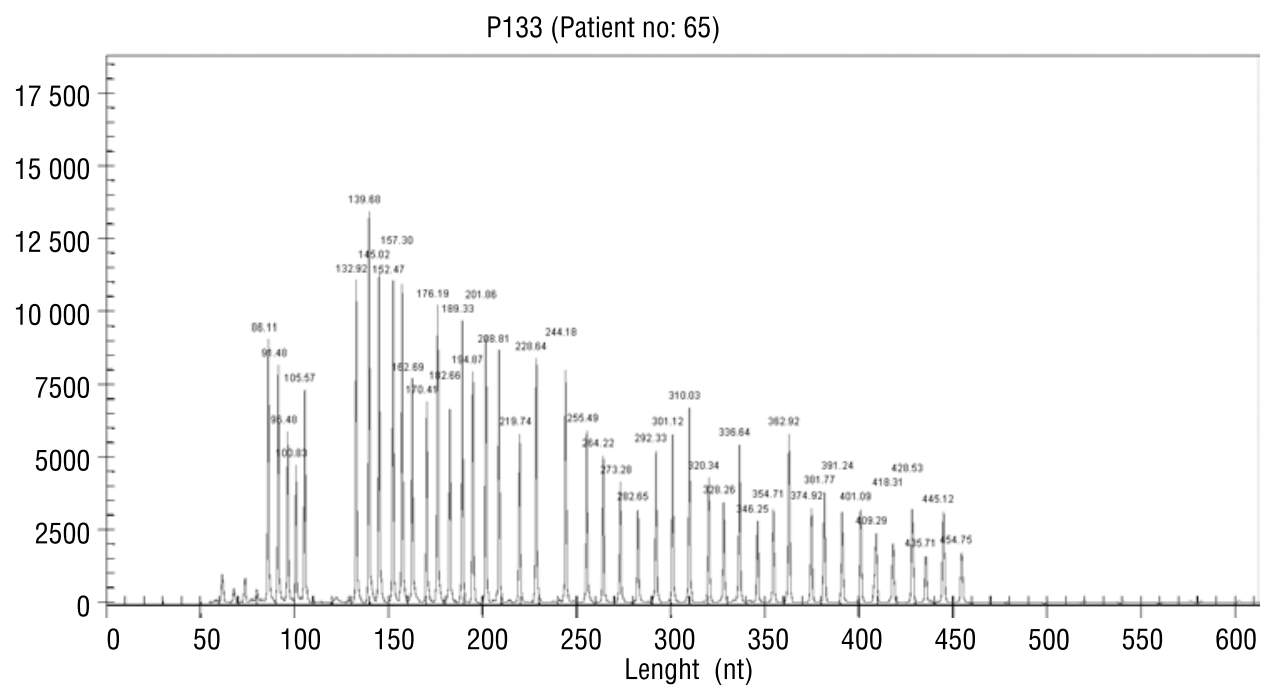

Figure 5. Deletion in exon 2 of the GNRHR gene (probe target sequence: 4447-L05586)

Rycina 5. Delecja w egzonie 2 genu GNRHR (sekwencja docelowa sondy: 4447-L05586)

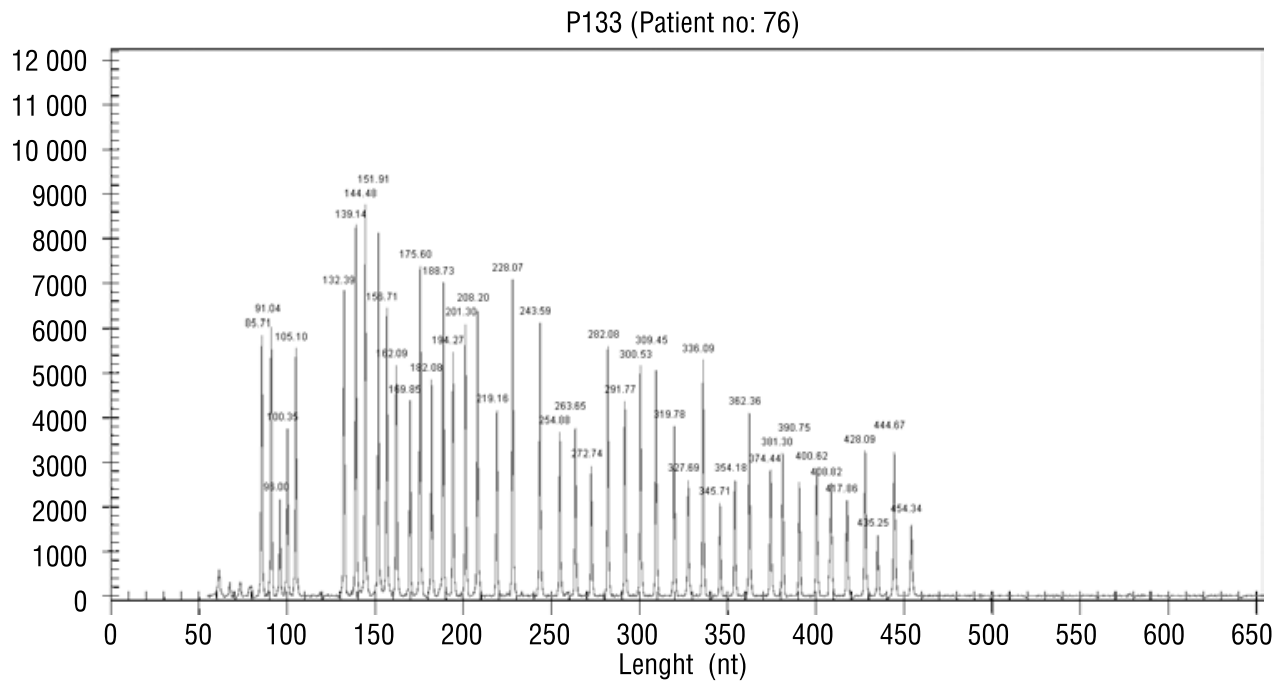

Figure 6. Duplication in exon 1 of the GNRHR gene (probe target sequence: 4445-L03831)

Rycina 6. Duplikacja w egzonie 1 genu GNRHR (sekwencja docelowa sondy: 4445-L03831) 
Table II. Characteristics of genomic variations in the patient group

Tabela II. Charakterystyka zmienności genetycznych w grupie pacjentów

\begin{tabular}{lcccccc}
\hline Patient No. & Length (nt) & SALSA MLPA probe & Exon & Ligation site & $\begin{array}{c}\text { Partial sequence (20 nt adjacent } \\
\text { to ligation site) }\end{array}$ & $\begin{array}{c}\text { Distance to } \\
\text { next exon }\end{array}$ \\
\hline 29 & 229 & 5941 -L05940 & KAL1 exon 9 & $1434-1435$ & AACTTGCAGT-CTGGAAGTCG & $14.4 \mathrm{~kb}$ \\
\hline 43 & 154 & $11953-L 12773$ & PROK2 exon 3 & Intron & CCCAGAAGAA-TTAGCCTTTA & $1.6 \mathrm{~kb}$ \\
\hline 65 & 283 & $4447-L 05586$ & GNRHR exon 2 & $2415-2416$ & CTCTTCATCA-TCCCTCTTTT & $4.0 \mathrm{~kb}$ \\
\hline 76 & 148 & $4445-L 03831$ & GNRHR exon 1 & $426-427$ & ACTGGTCTAA-GCTGCTCAAG & $1.6 \mathrm{~kb}$ \\
\hline 81 & 229 & $5941-L 05940$ & KAL1 exon 9 & $1434-1435$ & AACTTGCAGT-CTGGAAGTCG & $14.4 \mathrm{~kb}$ \\
\hline 84 & 265 & $4427-L 03813$ & KAL1 exon 11 & $1737-1738$ & TAAGGGGAAG-AGCCACAAGC & $2.9 \mathrm{~kb}$ \\
\hline
\end{tabular}

abnormalities were more profound in those with KAL1 genomic rearrangements. No phenotypic abnormality was observed in the control group.

\section{Discussion}

In the present study we aimed to determine the prevalence of KAL1, PROK2, PROKR2, GNRH1 and GNRHR copy number variations in Turkish patients with $\mathrm{IHH}$, using MLPA. The KAL1 gene is located on chromosome Xp22.3 and loss of KAL1 function is responsible for the $X$-linked form of the KS [1]. Mutations in the PROKR2 and PROK2 genes, which are located on chromosomes 20p12.3 and 3p13, are likely to be involved both in autosomal recessive monogenic and digenic/oligogenic transmission modes [2]. The gene encoding GNRHR is located on chromosome $4 \mathrm{q} 21.2$ and mutations in the GnRHR are transmitted as an autosomal recessive trait. Although human GNRH1 gene mutations have not been reported yet, a gene located on chromosome 8p21-11.2, loss of GNRH1 function was shown to be responsible for the autosomal recessive inheritance of IHH in an animal study [3].

İHH is a clinically and genetically heterogeneous disease, the genetic basis of which remains unknown in the majority of cases. It has been clinically classified into two major subgroups, $\mathrm{KS}$ and $\mathrm{nIHH}$, depending on the presence or absence of a normal sense of smell. Patients with KS have either diminished (hyposmia) or absent (anosmia) sense of smell, in contrast to those with $\mathrm{nIHH}$, whose sense of smell is normal [4]. As a result of their genetic heterogeneity, both disorders may occur as a part of various genetic defects. To date, several loss of function mutations in different genes have been described, resulting in recessive-X-linked, autosomal dominant and autosomal recessive modes of inheritance. These genetic causes account together for less than $30 \%$ [5], and much still remains to be discovered and understood regarding the underlying pathological processes. The underlying causes may be due to mutations involved in the multiple steps of normal reproduction, such as $\mathrm{GnRH}$ neuronal migration and function, GnRH synthesis and secretion, hypophyseal response to $\mathrm{GnRH}$, and gonadotropin biosynthesis.

The KAL1 gene encodes anosmin-1, a neural cell adhesion molecule that modulates the migration of neuroendocrine GnRH cells from the olfactory epithelium to the hypothalamus during foetal development $[6,7]$. Consequently, hypogonadism in KS is due to GnRH deficiency, which most probably results from a failure of this embryonic neuronal migration [8. 9], and the defective sense of smell is related to the hypoplasia or aplasia of the olfactory bulbs and tracts [10]. The KAL1 gene was first reported as being defective in patients with KS by Franco et al. and Legouis et al. in 1991 [11, 12], whereas Bick et al. identified the first intragenic deletion of the KAL1 gene in 1992 [13]. Different mutations, widely distributed throughout the 14 exons of the gene, have been described in KS patients. However, these genetic defects have been discovered only in approximately $10 \%$ of KS patients [14]. The prevalence of KAL1 mutations in apparent sporadic forms of IHH, with or without anosmia, has been variably reported to range from $3.1 \%$ to $27.8 \%$ [15, 16]. Bhagavath et al. stated that the overall frequency of KAL1 mutations might not be as prevalent as previously estimated. The prevalence reported in $138 \mathrm{IHH}$ patients ( 109 males and 29 females) was $3.7 \%$ for male patients with $\mathrm{nIHH}$ and $6.3 \%$ for male patients with $\mathrm{KS}$, although no mutation was detected in females [17].

In the present study, three patients with $\mathrm{IHH}$ had a deletion in exon 9 of the KAL1 gene (probe target sequence: 5941-L05940) and one of these patients also carried a duplication in exon 11 of the same gene (probe target sequence: 4427-L03813). The prevalence of the 
genomic rearrangements in the KAL1 was found to be $3.4 \%$ among the patient group, which was consistent with the previous studies. When the $\mathrm{IIHH}$ and KS patients were considered separately it was $3.9 \%$ among the patients with $\mathrm{nIHH}$ and $30 \%$ among the patients with KS.

The best known smell identification test in the literature is The University of Pennsylvania Smell Identification Test (UPSIT) [18]. However, there are no standardised olfaction scores for the Turkish population. Clinical assessment of olfactory function in our study population was performed qualitatively by asking the subjects to identify strong odours such as coffee, onion, garlic etc. For more accurate diagnosis, the olfactory tracts and bulbs of each patient were also examined by MRI, which is the most preferred imaging technique for the evaluation of olfactory disorders. However, MRI scans of the olfactory pathways revealed no abnormality in the study population, including those with KS. On the other hand, craniofacial and dental anomalies, such as high-arched palate and malocclusion, were observed in all KS patients on physical examination, suggesting that KAL1 genomic rearrangements might be associated with more profound phenotypic consequences. Human studies have shown that other midline craniofacial abnormalities (including cleft palate, cleft lip or choanal atresia), involuntary upper limb mirror movements (bimanual synkinesis), dental or renal agenesis, sensorineural deafness, oculomotor deficits, and other less documented developmental disorders may also occur in these patients [19].

It has been shown that the genes encoding ligand PROK2 and its related G protein-coupled receptor (PROKR2) are also essential for normal olfactory bulb and reproductive system development in mice [20] and in patients with $\mathrm{IHH}[21,22]$. Homozygous mutant mice, that do not exhibit this transmembrane receptor, show abnormal development of the olfactory bulb and severe atrophy of the reproductive system, but no significant abnormalities were observed in the heterozygous mice [23]. It has been reported that higher anosmin-1 levels in heterozygous mutant mice are protective from these developmental failures [24]. Mutations described within the PROK2/PROKR2 system account for less than $10 \%$ of subjects with $\mathrm{KS}$ and $\mathrm{nIHH}[21,22]$. In a large group of hypogonadal patients ( 170 with $\mathrm{KS}$ and 154 with $\mathrm{nIHH}$ ), Cole et al. identified PROK2 gene mutations to cause KS and $\mathrm{nIHH}$ in $2 \%$ and less than $1 \%$ of cases, respectively. However, PROKR2 gene mutations were described in $4 \%$ of KS patients and 3\% of patients with $\mathrm{nIHH}$ [25]. Interestingly, cases presenting with mutations in both KAL1 and PROKR2 genes have been rarely reported, suggesting possible digenic inheritance in KS [10, 26]. In the present study, only one patient with nIHH had a duplication in exon 3 of the PROK2 gene (probe target sequence: 11953-L12773), and the prevalence was found to be $1.1 \%$ among the patient group, which was comparable with the previous data. However, no deletion or duplication was detected in the PROKR2 gene. When the nIHH and KS patients were considered separately, it was $1.3 \%$ among the patients with $\mathrm{nIHH}$ and $0 \%$ among the patients with $\mathrm{KS}$.

Mutations in the GNRHR gene were first defined by de Roux et al. in 1997 [27], and subsequently around 20 different mutations have been reported in patients with sporadic or familial IHH [28]. The prevalence of GNRHR gene mutations was reported to account for $40 \%$ in familial and $16.7 \%$ in sporadic nIHH cases [29]. Although they were shown to be responsible for hypogonadotropic hypogonadism in animal studies, human studies failed to identify GNRH1 gene mutations. In the present study, two GNRHR gene deletions (one in exon 2 (probe target sequence: 4447-L05586) and another in exon 1 (probe target sequence: 4445-L03831)) were identified in patients with nIHH. The prevalence of the genomic rearrangements in the GNRHR was found to be $2.3 \%$ among the patients with $\mathrm{IHH}$, less common than the prevalence reported in the literature. No copy number variation was described in the GNRH1 gene. When considered independently, the percentage was 2.6 among the patients with $\mathrm{nIHH}$ and $0 \%$ among the patients with KS.

Because the patients with the above-mentioned gene rearrangements in the present study had no family history of delayed sexual development, hypogonadism or defective smell sense, these genomic variations were thought to be sporadic in occurrence. However, previous familial history of affected individuals is also unlikely due to autosomal recessive inheritance of GNRH1, GNRHR, PROK2, PROKR2 and some forms of KAL1 gene mutations,

MLPA is a relatively new and effective technique for detecting deletions and duplications in genomic sequences [30]. To date, most of the prevalence studies have used PCR-based DNA sequencing in detecting point mutations and small deletions or duplications [31]. Amplification of the remaining normal allele makes this traditional technique unable to detect heterozygous gene deletions and duplications. Copy number variations that escape detection using current PCR-based techniques were found in patients with cystic fibrosis [32] and breast/ovarian cancer [33] using MLPA, suggesting that a considerable number of mutations are likely to remain undiagnosed. However, gene deletions have been identified in an approximately similar percentage by MLPA, compared to previous studies using the traditional PCR-based sequencing methods [34]. 
IHH is an important health problem and most cases are potentially treatable either with testosterone, or gonadotropin/GnRH replacement. However, correct clinical and genetic diagnosis of this condition is essential. Hence, analysis of genetic defects can help to confirm the clinical diagnosis and may also be a practical method for carrier detection, genetic counselling and prenatal diagnosis, particularly in families with no mutation. Because MLPA reaction is fast, cheap and very simple to perform, it may be more easily incorporated into clinical applications.

\section{Conclusion}

In recent years, several genes involved in the development of hypothalamic-pituitary-gonadal axis have been identified. However, mutations in the prescribed genes account for a small minority of cases, signifying that other genes may be involved in the pathogenesis of IHH. Further studies of genes that regulate hypothalamicpituitary-gonadal development and functions should be carried out to clarify the additional genetic defects.

For detecting genomic deletions and duplications, MLPA has advantages over the traditional methods because of its simplicity, relatively low cost, and efficiency.

\section{References}

1. Hardelin JP, Levilliers J, del Castillo I et al. X chromosome-linked Kallmann syndrome: stop mutations validate the candidate gene. Proc Natl Acad Sci 1992; 89: 8190-8194.

2. Dodé C, Teixeira L, Levilliers J et al. Kallmann syndrome: mutations in the genes encoding prokineticin-2 and prokineticin receptor-2. PloS Genet 2006; 2: 1648-1652.

3. Mason AJ, Hayflick JS, Zoeller RT et al. A deletion truncating the gonadotropin-releasing hormone gene is responsible for hypogonadism in the hpg mouse. Science 1986; 234: 1366-1371.

4. Kallmann FJ, Schoenfeld WA, Barrera SE. The genetic aspects of primary eunuchoidism. Am. J. Ment. Defic 1944; 48: 203-236.

5. Dodé C, Hardelin JP. Clinical genetics of Kallmann syndrome. Ann Endocrinol 2010; 71: 149-157.

6. Schwanzel-Fukuda M. Origin and migration of luteinizing hormonereleasing hormone neurons in mammals. Microsc Res Tech 1999; 44: 2-10.

7. Gonzalez-Martinez D, Kim S, Hu Y et al. Anosmin-1 modulates fibroblast growth factor receptor 1 signaling in human gonadotropin-releasing hormone olfactory neuroblasts through a heparan sulfate-dependent mechanism. J Neurosci 2004; 24: 10384-10392.

8. Naftolin F, Harris GW, Bobrow M. Effect of purified luteinizing hormone releasing factor on normal and hypogonadotropic anosmic men. Nature 1971; 232: 496-497.

9. Schwanzel-Fukuda M, Bick D, Pfaff DW. Luteinizing hormone releasing hormone (LHRH)-expressing cells do not migrate normally in an inherited hypogonadal (Kallmann) syndrome. Mol Brain Res 1989; 6: 311-326.

10. de Morsier G. Median cranioencephalic dysraphias and olfactogenital dysplasia. World Neurol 1962; 3: 485-504.

11. Franco B, Guioli S, Pragliola A et al. A gene deleted in Kallmann's syndrome shares homology with neural cell adhesion and axonal pathfinding molecules. Nature 1991; 353: 529-536.
12. Legouis R, Hardelin JP, Levilliers J et al. The candidate gene for the $\mathrm{X}$-linked Kallmann syndrome encodes a protein related to adhesion molecules. Cell 1991; 67: 423-435.

13. Bick D, Franco B, Sherins RJ et al. Brief report: intragenic deletion of the KALIG-1 gene in Kallmann's syndrome. N Engl J Med 1992; 326: 1752-1755.

14. Laitinen EM, Vaaralahti $\mathrm{K}$, Tommiska J et al. Incidence, phenotypic features and molecular genetics of Kallmann syndrome in Finland. Orphanet J Rare Dis 2011; 17: 41

15. Sato N, Katsumata N, Kagami M et al. Clinical assessment and mutation analysis of Kallmann syndrome 1 (KAL1) and fibroblast growth factor receptor 1 (FGFR1, or KAL2) in five families and 18 sporadic patients. J Clin Endocrinol Metab 2004; 89: 1079-1088.

16. Albuisson J, Pecheux C, Carel JC et al. Kallmann syndrome: 14 novel mutations in KAL1 and FGFR1 (KAL2). Hum Mutat 2005; 25: 98-99.

17. Bhagavath $B, X u N$, Ozata $M$ et al. KAL1 mutations are not a common cause of idiopathic hypogonadotrophic hypogonadism in humans. Mol Hum Reprod 2007; 13: 165-170.

18. Doty RL, Shaman P, Kimmelman CP et al. University of Pennsylvania Smell Identification Test: a rapid quantitative olfactory function test for the clinic. Laryngoscope 1984; 94: 176-178.

19. Tsai PS, Gill J. Mechanisms of disease: Insights into X-linked and autosomal-dominant Kallmann syndrome. Nat Clin Pract Endocrinol Metab 2006; 2: 160-171.

20. 20. Ng KL, Li JD, Cheng MY et al. Dependence of olfactory bulb neurogenesis on prokineticin 2 signaling. Science 2005; 308: 1923-1927.

21. Pitteloud N, Zhang C, Pignatelli D et al. Loss-of-function mutation in the prokineticin 2 gene causes Kallmann syndrome and normosmic idiopathic hypogonadotropic hypogonadism. Proc Natl Acad Sci U S A 2007; 104: 17447-17452.

22. Martin C, Balasubramanian R, Dwyer AA et al. The role of the prokineticin 2 pathway in human reproduction: evidence from the study of human and murine gene mutations. Endocr Rev 2011; 32: 225-246.

23. Matsumoto S, Yamazaki C, Masumoto KH et al. Abnormal development of the olfactory bulb and reproductive system in mice lacking prokineticin receptor PKR2. Proc Natl Acad Sci 2006; 103: 4140-4145.

24. Salido EC, Li XM, Yen PH et al. Cloning and expression of the mouse pseudoautosomal steroid sulphatase gene (Sts). Nat Genet 1996; 13: 83-86.

25. Cole LW, Sidis Y, Zhang C et al. Mutations in Prokineticin 2 and Prokineticin receptor 2 genes in Human Gonadotrophin-Releasing Hormone Deficiency: Molecular Genetics and Clinical Spectrum. J Clin Endocrinol Metab 2008; 93: 3551-3559.

26. Canto P, Munguía P, Söderlund D et al. Genetic analysis in patients with Kallmann syndrome: coexistence of mutations in prokineticin receptor 2 and KAL1. J Androl 2009; 30: 41-45.

27. de Roux N, Young J, Misrahi M et al. A family with hypogonadotropic hypogonadism and mutations in the gonadotropin-releasing hormone receptor. N Engl J Med 1997; 337: 1597-1602.

28. Trarbach EB, Silveira LG, Latronico AC. Genetic insights into human isolated gonadotropin deficiency. Pituitary 2007; 10: 381-391.

29. Beranova M, Oliveira LM, Bedecarrats GY et al. Prevalence, phenotypic spectrum, and modes of inheritance of gonadotropin-releasing hormone receptor mutations in idiopathic hypogonadotropic hypogonadism. J Clin Endocrinol Metab 2001; 86: 1580-1588.

30. Schouten JP, McElgunn CJ, Waaijer R et al. Relative quantification of 40 nucleic acid sequences by multiplex ligation-dependent probe amplification. Nucleic Acids Res 2002; 30: e57.

31. Kim HG, Bhagavath B, Layman LC. Clinical Manifestations of Impaired GnRH Neuron Development and Function. Neurosignals 2008; 16: 165-182.

32. Audrezet MP, Chen JM, Raguenes O et al. Genomic rearrangements in the CFTR gene: extensive allelic heterogeneity and diverse mutational mechanisms. Hum Mutat 2004; 23: 343-357.

33. Hogervorst FB, Nederlof PM, Gille JJ et al. Large genomic deletions and duplications in the BRCA1 gene identified by a novel quantitative method. Cancer Res 2003; 63: 1449-1453.

34. Pedersen-White JR, Chorich LP, Bick DP et al. The prevalence of intragenic deletions in patients with idiopathic hypogonadotropic hypogonadism and Kallmann syndrome. Mol Hum Reprod 2008; 14: $367-370$. 